\title{
Green Manures and Crop Sequences Influence Potato Diseases and Pathogen Inhibitory Activity of Indigenous Streptomycetes
}

\author{
B. E. Wiggins and L. L. Kinkel
}

Department of Plant Pathology, 495 Borlaug Hall, 1991 Upper Buford Circle, University of Minnesota, St. Paul 55108. Current address of B. E. Wiggins: Department of Plant Microbiology and Pathology, University of Missouri, Columbia 65211. Accepted for publication 20 September 2004.

\section{ABSTRACT}

Wiggins, B. E., and Kinkel, L. L. 2005. Green manures and crop sequences influence potato diseases and pathogen inhibitory activity of indigenous streptomycetes. Phytopathology 95:178-185.

A 2-year field trial was conducted to determine the effects of green manures and crop sequences on potato scab and Verticillium wilt. In addition, indigenous streptomycete densities and in vitro pathogen inhibitory activity were measured and their relationships to plant disease were determined. Green manures (buckwheat, canola, or fallow controls) were tested in conjunction with three crop sequences (alfalfa-potato, cornpotato, and potato-potato). Compared with fallow controls, tubers grown in buckwheat-treated soil had significantly lower Verticillium wilt ratings, and tubers grown in buckwheat- or canola-treated soil had greater yields. Potatoes grown in soil planted to corn or alfalfa the previous year had significantly lower Verticillium wilt and potato scab ratings as well as higher yields than potatoes grown in soil previously planted to potato. Streptomycetes from soils collected from green manure-treated plots tended to have greater in vitro pathogen inhibitory activity than streptomycetes from fallow-treated plots. Furthermore, streptomycete pathogen inhibitory activity was frequently negatively correlated with plant disease and positively correlated with potato yield. These results indicate that green manure treatments may contribute to active management of the pathogen inhibitory activity of the streptomycete community to achieve plant disease control.
The control of soilborne plant pathogens presents a challenge to potato growers. Although disease-resistant potato varieties are available, resistance is often incomplete. Chemical control, when available, may not be suitable due to the economic costs and environmental risks associated with application. Two common soilborne pathogens of potato, Streptomyces scabies (Thaxter) Lambert \& Loria (25), the cause of potato scab, and Verticillium dahliae Kleb., the cause of Verticillium wilt, represent especially important challenges to potato growers. Both diseases can cause significant yield and quality losses, and current control methods for these diseases are inadequate (18).

Organic soil amendments, including green manures (GMs), have been studied as a potential control strategy for these diseases. Though GMs offer substantial benefits to the soil including increased organic matter and nutrients, improved soil structure, and weed and erosion control $(1,2,4)$, disease control through the use of GMs is often inconsistent $(9,26,34-37,40,41,46,47)$. The inconsistent results among these studies likely reflect the varying conditions and circumstances under which the experiments were conducted, including the use of diverse GM species, different soil types and potato cultivars, varying pathogen inoculum densities, and the use of naturally versus artificially infested soils.

The mechanisms by which GMs may influence disease are varied and often unknown. GMs may influence pathogens directly through the breakdown of glucosinolates (7) or by releasing fungitoxic compounds such as avenacin, saponins $(11,14)$, or allyl isothiocyanate (32). GMs may also affect soilborne pathogens indirectly by influencing indigenous microbial populations. For example, incorporation of soil amendments has been shown to increase soil microbial activity (10), microbial diversity (31), and densities of bacteria $(16,33,37)$, fluorescent Pseudomonas spp.

Corresponding author: B. E. Wiggins; E-mail address: wigginsb@missouri.edu

DOI: 10.1094/PHYTO-95-0178

(C) 2005 The American Phytopathological Society
(5,8,33), nonpathogenic Fusarium spp. (10), mycophagous organisms (42) and streptomycetes, and other actinomycetes $(16,24,33)$ in soil. These changes in the microbial community may affect pathogen populations through competition, parasitism, predation, or antagonism $(19,36,42,45)$.

Research in our laboratory has focused on manipulating the indigenous soil microbial community, specifically the streptomycete community, in an attempt to achieve disease control. Streptomycetes are gram-positive bacteria that are ubiquitous in soil (15). Their prolific antibiotic production has made them the subject of numerous studies on the biological control of plant-pathogenic bacteria, fungi, and nematodes. The addition of antagonistic streptomycetes has been shown to reduce diseases caused by Streptomyces (28), Phytophthora (22,48), Pythium $(6,22,49)$, Verticillium (13), Rhizoctonia (6), Fusarium (6), and Pratylenchus spp. (39). However, control of soilborne pathogens using added antagonists is often inconsistent and unpredictable (38). Enhancing the pathogen inhibitory activities of the indigenous soil microbial community, specifically the streptomycetes, offers a potential alternative for plant disease control.

The objectives of this research were to determine the effects of GMs (buckwheat, canola, and a fallow control) and crop sequences (alfalfa-potato, corn-potato, and potato-potato) on plant disease, streptomycete and bacterial densities, and pathogen inhibition by indigenous streptomycetes, and to determine the relationship between shifts in pathogen inhibition by streptomycetes and plant disease. To meet these objectives, a 2-year field trial was conducted in which GMs were tested in conjunction with three crop sequences in all possible combinations.

\section{MATERIALS AND METHODS}

A field trial was conducted at the Sand Plain Research Farm in Becker, MN, in Hubbard Loamy Sand with low soil organic matter $(1.9 \%)$ and $\mathrm{pH}$ of 5.2 . The field site had a history of moderate to heavy potato scab disease and was planted to rye in 
the season preceding this study. Three treatments (two GMs [canola and buckwheat] and a fallow control) were evaluated in conjunction with three production crop sequences (alfalfa-potato, corn-potato, and potato-potato). Plots, 13.7 by $6.1 \mathrm{~m}^{2}$, were established in a split-plot design with the crop as the whole plot factor and GM as the split-plot factor. Four replicates were established for each $\mathrm{GM} \times$ crop sequence combination. GM treatments were applied to plots in the spring of 2001 followed by the three crop treatments. A second GM cycle was sown in the fall of 2001. An early frost, however, killed the GM so a third cycle was sown in the spring of 2002. All plots were sown to potato the summer of 2002.

GM crops were sown on 18 April 2001, 14 September 2001, and 30 April 2002. Common buckwheat (Fagopyrum esculentum, $451 \mathrm{~kg} / \mathrm{ha}$ in April 2001; 'Mancan', $112 \mathrm{~kg} / \mathrm{ha}$ in September 2001 and April 2002) and canola ('Impact', $54 \mathrm{~kg} / \mathrm{ha}$ in April 2001; and 'Hyola 401', 20 kg/ha in September 2001 and April 2002) were broadcast in plots and raked into the soil. GMs were incorporated into the soil with a rotovator on 29 May 2001 and 19 June 2002, and production crops were planted the same day.

Potatoes ('Kennebec' cut seed pieces having no visible scab symptoms, $1.2-\mathrm{m}$ row spacing, sown approximately $30 \mathrm{~cm}$ apart), sweet corn ('Bodacious', $17 \mathrm{~kg} / \mathrm{ha}$ ), and alfalfa ('Nitro', $10 \mathrm{~kg} / \mathrm{ha}$ ) were sown in 2001 according to standard practices. In 2002, all plots were sown to potato ('Kennebec') in the same manner as in 2001. Crops were irrigated as needed and managed according to standard practices.

On 9 September 2001 and 27 September 2002, potato tubers were harvested and removed from the field. Remaining crops were harvested according to standard techniques; alfalfa was cut and removed from the field, and corn stalks were chopped and incorporated into the soil.

Soil samples were taken throughout the growing season in both years of the study (18 April, 30 July, and 8 September 2001 and 30 April and 9 July 2002). At each sampling time, six soil cores (2-cm-diameter by $15 \mathrm{~cm}$ ) per split-plot were collected from random locations in the center of each split-plot, bulked, and stored at $4^{\circ} \mathrm{C}$ until processed as described below.

Potato health assessment. In the first year of the trial, tubers were sampled from 10 potato plants randomly selected from the middle of each split-plot. All harvested tubers were weighed, and 20 randomly selected tubers from each plot were rinsed with water and rated for scab. The percent surface area of each tuber covered with scab lesions (percent scab) was estimated, and the number of scab lesions of type 2 or 3 and of type 4 or 5 ( $2=$ small superficial lesions, $3=$ periderm broken, $4=$ pit, and $5=$ deep pit) were counted per tuber as described by Liu et al. (28). In 2002, five randomly selected plants were dug from the center of each split-plot, and eight randomly selected tubers were collected from each plant. Tubers were washed, and only tuber weight and percent scab were recorded due to time constraints.

In 2002, potato plants were assessed for vascular colonization of Verticillium spp. (disease severity) according to the culture plate method described by Hoyos et al. (20). On 23 September 2002, basal stem sections were sampled from five randomly selected plants from the middle of each split-plot. Subsequently, Verticillium colonization was rated on a 0 -to- 8 scale based on the approximate number of colony forming units (CFU) per $0.1 \mathrm{ml}$ of stem sap: $0=0$ to $10 ; 1=11$ to $30 ; 2=31$ to $100 ; 3=101$ to 300 ; $4=301$ to $800 ; 5=801$ to 2,$000 ; 6=2,001$ to 6,$000 ; 7=6,001$ to 18,000 ; and $8=18,001$ to 50,000 (44).

Microbial community analyses: population densities and pathogen inhibition. Microbial community analyses included assessment of streptomycete and total bacterial population densities in soil and in vitro assessment of antibiotic inhibition among streptomycetes isolated from soil. Correspondence among these measures is also considered to provide insight into the potential origins of disease suppression in different soils.
Soil streptomycete and bacterial populations. Streptomycete densities in soil were estimated using a modification of a method described by Herr (17). Soil samples were dried overnight under three layers of sterile cheesecloth at room temperature. Soil was ground with a sterile spoon until fine, and $5.0 \mathrm{~g}$ of the soil was added to $50 \mathrm{ml}$ of sterile water and shaken at $175 \mathrm{rpm}$ for $60 \mathrm{~min}$ at $4{ }^{\circ} \mathrm{C}$. Each soil wash suspension was serially diluted and 50 to $100 \mu \mathrm{l}$ of the diluent was spread onto two plates of water agar (WA; $10 \mathrm{~g}$ of Bacto agar per liter). Subsequently, plates were overlaid with $5.0 \mathrm{ml}$ of molten starch casein agar (SCA) (3), allowed to solidify, and incubated at $28^{\circ} \mathrm{C}$ for 5 days. This semiselective double layer agar method (WA/SCA) resulted in the growth of predominantly streptomycetes whose densities (CFU/g of soil) were estimated based on colony morphology. All soil samples from 2002 were also dilution-plated onto two plates of oatmeal agar (OA) (30) amended with cycloheximide $(50 \mu \mathrm{g} / \mathrm{ml})$. Plates were incubated at $28^{\circ} \mathrm{C}$ for 5 days after which bacterial densities were estimated from the numbers of culturable bacteria (CFU/g of soil) on each plate.

In vitro assays of pathogen inhibition by streptomycetes. The effects of GM and crop sequence on in vitro inhibitory activity of soil streptomycetes against pathogenic Streptomyces, Verticillium, Fusarium, and Rhizoctonia spp. were assessed using a modification of a method described by Herr (17). Soil dilutions were performed as described previously and plated onto agar plates containing 10 to $15 \mathrm{ml}$ of WA. Plates were then overlaid with $5.0 \mathrm{ml}$ of molten SCA for all Fusarium assays and all Verticillium assays in the first year of the trial. For all other pathogen assays, $5.0 \mathrm{ml}$ of molten WA was transferred to soil dilution plates. Each soil sample $\times$ pathogen combination was assessed on three plates. All plates were incubated at $28^{\circ} \mathrm{C}$ for 3 days prior to inoculation of pathogen targets (described below). In vitro pathogen inhibitory activity was determined by overlaying each soil dilution plate with medium and one of four pathogens: S. scabies (strain 87; obtained from D. Liu; isolated from potato in Grand Rapids, MN) (27), R. solani (ATCC 44660, anastomosis group 3, isolated from potato, obtained from N. Anderson), V. dahliae (strain VA33A, VCG 4A, isolated from potato, obtained from N. Anderson), or F. oxysporum f. sp. medicaginis (strain 31FS, isolated from alfalfa, obtained from D. Samac), as described below.

S. scabies. Ten milliliters of SCA was transferred onto each soil dilution plate and overlaid with $150 \mu \mathrm{l}$ of a $20 \%$ glycerol suspension containing approximately $10^{8} \mathrm{CFU} / \mathrm{ml}$ of $\mathrm{S}$. scabies. Plates were incubated at $28^{\circ} \mathrm{C}$ for 3 days.

V. dahliae. Ten milliliters of potato dextrose water agar (PDWA; $2.4 \mathrm{~g} /$ liter, potato dextrose broth [Difco Laboratories, Detroit] $10 \mathrm{~g} /$ liter of Bacto agar) was transferred onto each soil dilution plate. Subsequently, $10 \mathrm{ml}$ of sterile water was added to a 7-dayold culture of $V$. dahliae growing on $\mathrm{OA}$, and spores and mycelia were loosened by scraping with a sterile loop. Next, $150 \mu \mathrm{l}$ of the resulting pathogen suspension was spread over each soil dilution plate. Plates were incubated for 2 days at room temperature.

In the second year of the study, a slightly different procedure was followed that was more time efficient and resulted in clearer inhibition zones. Instead of plating the pathogen on top of the medium, $7.5 \mathrm{ml}$ of the pathogen suspension was added to 0.5 liters of molten PDWA and mixed thoroughly. Ten milliliters of this suspension was transferred to each soil dilution plate. Plates were incubated for 2 days at room temperature. Estimates of antagonist densities did not differ significantly between the two different procedures used in this study, though mean inhibition zone sizes measured from the inoculated media overlays were nearly twice as large as zones measured from the overlays in which pathogen suspensions were spread over the medium (data not shown).

F. oxysporum. A 7-day-old culture of F. oxysporum on potato dextrose agar (43) was cut into approximately $1-\mathrm{cm}^{2}$ pieces with a 
sterile knife and blended with $100 \mathrm{ml}$ of sterile water in a sterile flask of a Waring blender three times for $5 \mathrm{~s}$ each, and once for $10 \mathrm{~s}$. Four milliliters of this suspension was added to $100 \mathrm{ml}$ of molten PDWA, mixed thoroughly, and $10 \mathrm{ml}$ of the resulting suspension was overlaid on top of each soil dilution plate. Plates were incubated at room temperature for 1 day.

$\boldsymbol{R}$. solani. $R$. solani cultures were grown as still cultures in 250-ml flasks containing $25 \mathrm{ml}$ of Czapek-Dox broth (CZB; $35 \mathrm{~g} / \mathrm{liter}$; Difco Laboratories) for 7 days at $25^{\circ} \mathrm{C}$. The entire contents of two flasks were blended in a sterile flask of a Waring blender with $50 \mathrm{ml}$ of molten CZB containing $0.5 \mathrm{~g}$ of Bacto agar three times for $5 \mathrm{~s}$ each, and once for $10 \mathrm{~s}$. Subsequently, $10 \mathrm{ml}$ of the suspension was transferred to each soil dilution plate. Plates were incubated at $25^{\circ} \mathrm{C}$ for 2 days.

For all pathogens, inhibitory activity of streptomycetes was indexed by determining antagonist density, the proportion of antagonists, and the mean inhibition zone size of the streptomycetes. Antagonist density (CFU/g of soil) was determined by counting the number of streptomycetes that produced a clear inhibition zone against the target pathogen. The proportion of streptomycetes antagonistic against each pathogen (proportion of antagonists) was expressed as the density of antagonists divided by the streptomycete density. For every sample, the diameter of each inhibition zone was measured, and mean inhibition zone sizes were determined for each pathogen. For each soil sample, the mean inhibition zone size per streptomycete was calculated by multiplying each of the four mean inhibition zone sizes per antagonist by the proportion of antagonists of the respective pathogen.

Statistical analyses. Data were analyzed using SAS (release 8.0; SAS Institute, Cary, NC). Data were subjected to analysis of variance (proc glm) and Fisher's least significant difference test (LSD) using the split-plot model and Pearson correlations. Proportional data were angular-transformed (arcsine square root) prior to analysis to normalize the variance. In cases in which there was a significant effect of GM or crop on the studied variable prior to treatment, subsequent analyses were performed using the first soil sample data as a covariate. Changes in microbial community and pathogen inhibition before and after treatment were analyzed; differences among treatments were similar whether considering changes over time or differences at a single time following treatment. Only comparisons among treatments within a sampling time are presented here. There were no significant GM-crop treatment interactions unless stated.

The binomial test was used to detect the consistency of Pearson correlation coefficients for relationships among microbial com-

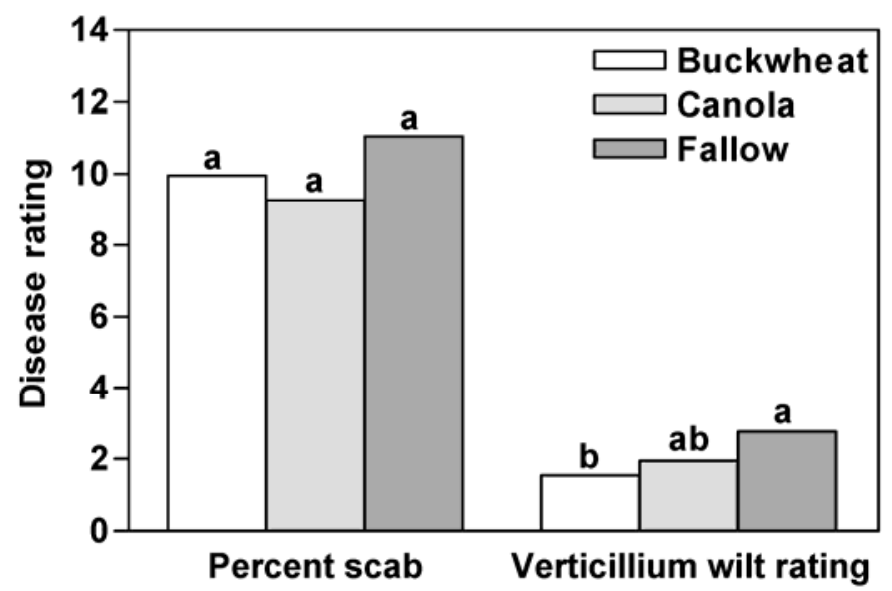

Fig. 1. Percent surface area covered with scab lesions (percent scab) and average Verticillium wilt rating of potatoes following two green manure treatments. Data shown are means of 11 (canola and fallow) or 12 (buckwheat) replicates per treatment. For each disease, treatments with different letters are significantly different $(P<0.05$, least significant difference). munity characteristics over times. Specifically, in cases where multiple independent correlation analyses were performed, the frequency of positive or negative correlation coefficients was counted, and the binomial $P$ value was calculated against the null hypothesis that correlation coefficients were completely random (12). The binomial test was also used to detect significant patterns in correlations between microbial community characteristics and plant disease.

\section{RESULTS}

The effects of GM and crop treatments on potato. Potato scab disease was high both years of the trial, though the mean percent surface area of each tuber covered with scab lesions (percent scab) was moderately higher in the first year of the trial $(17 \%)$ than in the second (10\%) among all plots. There were no significant differences in percent scab among GM treatments (buckwheat, canola, or fallow) either year of the study. However, in the first year of the trial, tubers grown in fallow-treated soils had marginally less scab disease than those grown in buckwheator canola-treated soils. For example, tubers grown in fallowtreated plots had somewhat lower percent scab and fewer type 2 or 3 lesions (10.4 and 16.4) than tubers grown in buckwheat(20.2 and $24.3 \%$ ) or canola- (22.1 and $28.1 \%)$ treated plots. In 2002, however, tubers grown in fallow-treated soil showed marginally greater scab than tubers grown in buckwheat- or canolatreated soils (Fig. 1). There was a significant effect of crop rotation (alfalfa, corn, or potato grown in the first year) on percent scab in the second year of the trial $\left(F_{2,9}=13.61, P=0.002\right)$. Tubers from plots previously planted to potato had a greater mean percent scab than tubers from plots previously planted to corn or alfalfa $(P<0.05$, LSD) (Fig. 2).

Verticillium wilt was assessed in 2002 only. GM treatment had a substantial effect on Verticillium wilt of potato $\left(F_{2,16}=3.40, P=\right.$ $0.059)$. Plant stems sampled from fallow-treated plots had significantly higher Verticillium wilt ratings than stems sampled from buckwheat-treated plots $(P<0.05$, LSD) (Fig. 1). Crop rotation also had a significant influence on Verticillium wilt rating $\left(F_{2,9}=\right.$ $8.06, P=0.010)$. Stems sampled from plots in which potato was grown the previous year had greater Verticillium wilt ratings than stems sampled from plots in which corn or alfalfa was grown previously $(P<0.05$, LSD) (Fig. 2).

Average tuber weight was not significantly affected by GM treatment in the first year of the study, though differences among treatments were marginally significant in the second year of the

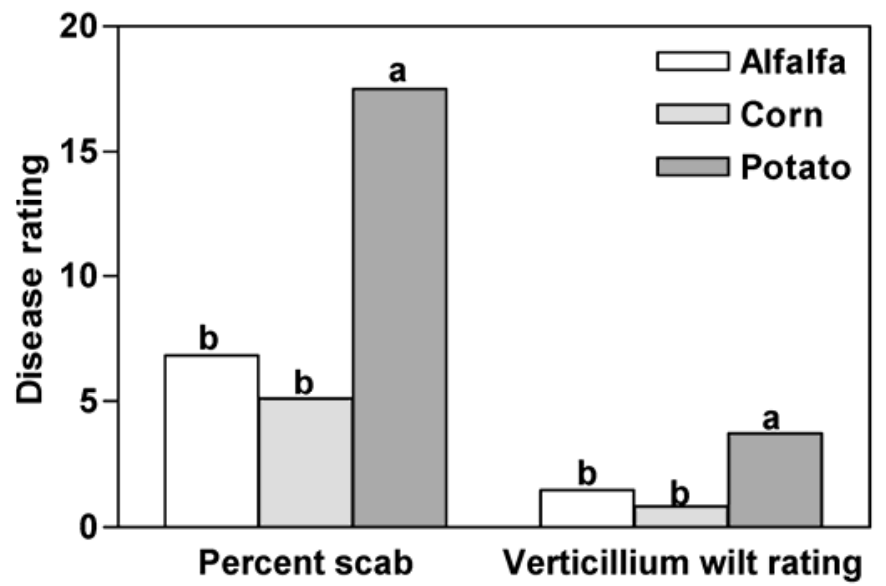

Fig. 2. Percent surface area covered with scab lesions (percent scab) and average Verticillium wilt rating of potatoes grown after different crops. Data shown are means of 10 (corn) or 12 (potato and alfalfa) replicates per treatment. For each disease, treatments with different letters are significantly different $(P<0.05$, least significant difference). 
trial $\left(F_{2,15}=3.04, P=0.078\right)$. In particular, tubers from fallowtreated plots had a lower average tuber weight $(160.5 \mathrm{~g})$ than those grown in buckwheat- or canola-treated plots (179.3 and $176.3 \mathrm{~g}$, respectively). In addition, tubers from plots previously planted to potato had a significantly lower average weight (146.1 g) than tubers from plots previously planted to corn $(190.9 \mathrm{~g})$ or alfalfa $(184.2 \mathrm{~g})(P<0.05$, LSD). Among all plots, mean tuber weight was negatively correlated with Verticillium wilt rating $(R=$ $-0.64, P<0.001)$ and percent scab $(R=-0.36, P=0.039)$ in 2002; more highly infected plants tended to have smaller tubers than healthy plants.

Soil microbial communities following GM and crop treatments: streptomycete and bacterial densities. Streptomycete densities varied significantly over time in all 36 experimental plots $\left(F_{3,136}=20.42, P<0.001\right)$. Among all plots, soil collected in September 2001 had greater streptomycete densities than at any other sampling time $(P<0.05, \mathrm{LSD})$. Despite the substantial temporal variability in streptomycete density, streptomycete densities within individual plots were significantly positively correlated among sampling dates $(R=0.36$ to $0.63, P<0.04$ in all cases). Thus, soils with relatively high streptomycete densities at one sampling time had relatively high streptomycete densities at other sampling times.

In general, bacterial and streptomycete densities were not affected by GM treatments. However, production crops had a significant effect on streptomycete density. For soil sampled in September 2001, soil from plots planted to potato had significantly greater streptomycete densities $\left(2.7 \times 10^{6} \mathrm{CFU} / \mathrm{g}\right)$ than soil from plots planted to corn $\left(2.5 \times 10^{6} \mathrm{CFU} / \mathrm{g}\right)$ or alfalfa $(2.0 \times$ $\left.10^{6} \mathrm{CFU} / \mathrm{g}\right)(P<0.05$, LSD). A similar trend was observed in streptomycete densities from soil collected in April 2002 (Table 1). Similarly, soil from plots previously planted to potato or corn had significantly greater bacterial densities than soil from plots previously planted to alfalfa (Table 1).

Density of pathogen antagonists. There were significant differences among the five sampling times in the density of streptomycetes antagonistic against $S$. scabies $\left(F_{4,175}=16.56, P<\right.$ $0.001), V$. dahliae $\left(F_{4,175}=6.01, P<0.001\right), F$. oxysporum $\left(F_{4,175}=5.15, P=0.001\right)$, and $R$. solani $\left(F_{4,175}=40.22, P<\right.$ $0.001)$. In addition, among all plots, antagonist densities in individual plots against each target pathogen except $R$. solani were consistently positively correlated among sampling times (30 of the 30 correlations were positive, $R=0.11$ to $0.60, P<0.0001$, binomial). Thus, plots with relatively high antagonist densities at one sampling time had relatively high antagonist densities at other sampling times.

Densities of antagonists varied among target pathogens. Across all plots and sampling dates, mean densities of streptomycetes antagonistic against $S$. scabies $\left(7.9 \times 10^{5} \mathrm{CFU} / \mathrm{g}\right)$ were higher than mean densities of streptomycetes antagonistic against $V$. dahliae $\left(5.1 \times 10^{5} \mathrm{CFU} / \mathrm{g}\right)$ or $R$. solani $\left(4.7 \times 10^{5} \mathrm{CFU} / \mathrm{g}\right)$; densities of streptomycetes antagonistic against $F$. oxysporum were lowest $\left(7.3 \times 10^{4} \mathrm{CFU} / \mathrm{g}\right)$. Despite these differences, antagonist densities for each of the target pathogens except $R$. solani were consistently positively correlated among pathogens within sampling times (15 of the 15 correlations were positive, $R=0.16$ to $0.71, P<0.0001$, binomial). Thus, if one plot had a relatively high density of antagonists of one pathogen, it had a relatively high density of antagonists of other pathogens, suggesting the potential for broad pathogen and disease suppression.

In general, there were few significant effects of GM on antagonist densities. Although not significantly different, buckwheatand canola-treated soils tended to have greater densities of streptomycetes antagonistic against $S$. scabies and $V$. dahliae than fallow-treated soil (Table 1). Antagonist densities were greatly affected by crop treatment. Soil from plots planted to potato in the first year of the trial tended to have the greatest densities of antagonists of S. scabies, V. dahliae, and R. solani (Fig. 3).

Proportions of pathogen antagonists and mean inhibition zone size. Both the proportion of antagonists and the intensity of pathogen inhibition (mean inhibition zone size) varied significantly among sampling times. For example, there were significant differences in the proportion of streptomycetes antagonistic against S. scabies (0.44 to $\left.0.61 ; F_{3,140}=4.67, P=0.004\right)$, V. dahliae $(0.23$ to $\left.0.43 ; F_{3,140}=14.09, P<0.001\right), F$. oxysporum $(0.03$ to 0.06 ; $\left.F_{3,140}=7.00, P<0.001\right)$, and $R$. solani $\left(0.27\right.$ to $0.39 ; F_{3,140}=4.24$, $P=0.007)$ among the last four soil samples. Despite this temporal variation, pathogen inhibitory activity (proportion of antagonists and mean inhibition zone size) against the four target pathogens was strongly positively correlated within sampling times (Table 2). Thus, streptomycete communities with relatively large patho-

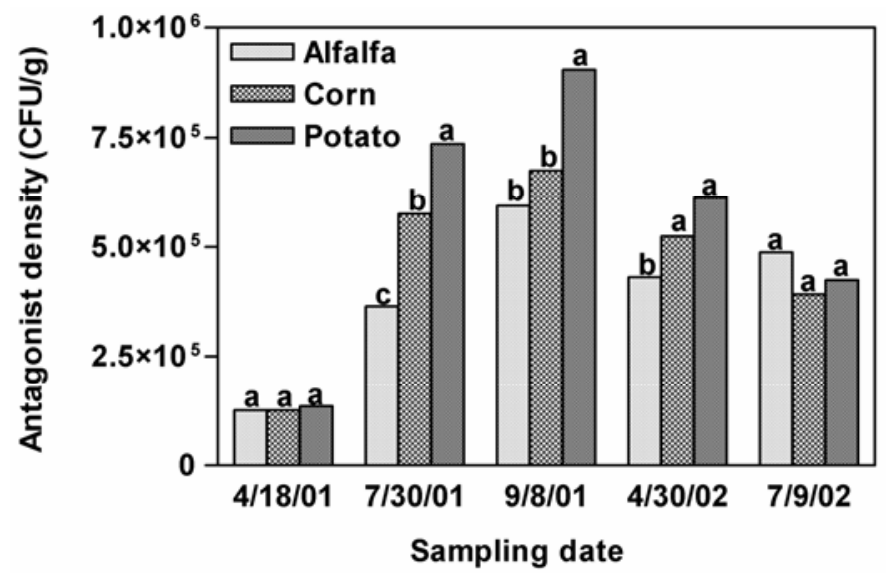

Fig. 3. Variation in densities of streptomycetes antagonistic against Rhizoctonia solani among crop treatments over time. Data shown are means of 12 replicates per treatment (10 for corn treatment on 9 July 2002). For each sample date, treatments with different letters are significantly different $(P<$ 0.05 , least significant difference).

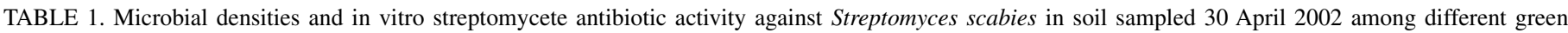
manure and crop treatments

\begin{tabular}{|c|c|c|c|c|c|c|}
\hline & Treatment & Bacterial density ${ }^{\mathrm{v}}$ & $\begin{array}{c}\text { Streptomycete } \\
\text { density }^{\mathrm{v}}\end{array}$ & Antagonist density ${ }^{\mathrm{w}}$ & $\begin{array}{c}\text { Proportion } \\
\text { of antagonists }^{\mathrm{x}}\end{array}$ & Inhibition zoney \\
\hline Green manure & $\begin{array}{l}\text { Buckwheat } \\
\text { Canola } \\
\text { Fallow }\end{array}$ & $\begin{array}{l}4.01 \mathrm{a}^{\mathrm{z}} \\
3.95 \mathrm{a} \\
3.75 \mathrm{a}\end{array}$ & $\begin{array}{l}1.32 \mathrm{~b} \\
1.26 \mathrm{~b} \\
1.53 \mathrm{a}\end{array}$ & $\begin{array}{l}7.38 \mathrm{a} \\
7.60 \mathrm{a} \\
6.78 \mathrm{a}\end{array}$ & $\begin{array}{l}0.53 \mathrm{ab} \\
0.60 \mathrm{a} \\
0.43 \mathrm{~b}\end{array}$ & $\begin{array}{l}5.9 \mathrm{a} \\
5.3 \mathrm{a} \\
6.0 \mathrm{a}\end{array}$ \\
\hline Crop & $\begin{array}{l}\text { Alfalfa } \\
\text { Corn } \\
\text { Potato }\end{array}$ & $\begin{array}{l}3.54 \mathrm{~b} \\
4.07 \mathrm{a} \\
4.16 \mathrm{a}\end{array}$ & $\begin{array}{l}1.24 \mathrm{~b} \\
1.34 \mathrm{~b} \\
1.54 \mathrm{a}\end{array}$ & $\begin{array}{l}6.49 \mathrm{~b} \\
6.49 \mathrm{~b} \\
8.78 \mathrm{a}\end{array}$ & $\begin{array}{l}0.53 \mathrm{a} \\
0.49 \mathrm{a} \\
0.56 \mathrm{a}\end{array}$ & $\begin{array}{l}5.8 \mathrm{a} \\
5.8 \mathrm{a} \\
5.6 \mathrm{a}\end{array}$ \\
\hline
\end{tabular}

$\mathrm{v} \times 10^{6} \mathrm{CFU} / \mathrm{g}$ soil.

${ }^{\mathrm{w}} \times 10^{5} \mathrm{CFU} / \mathrm{g}$ soil.

${ }^{x}$ Density of antagonists as a proportion of streptomycete density.

y Mean diameter of inhibition zone (millimeters).

z Values within a column for each set of treatments followed by different letters are significantly different $(P<0.05$, least significant difference). 
gen inhibitory activities against one pathogen had large inhibitory activities against several other pathogens, indicating the potential for broad range pathogen inhibition.

Streptomycetes from GM-treated soils (buckwheat and canola) tended to have greater pathogen inhibitory activities than soil from fallow-treated plots. However, the effects of GM on pathogen inhibition were generally noted well after GM incorporation. In September 2001, over 3 months after GM incorporation, a significantly greater proportion of streptomycetes from buckwheat-treated plots were antagonistic against S. scabies $(0.52)$ than streptomycetes from canola-treated plots (0.39); fallowtreated plots were intermediate $(0.41)(P<0.05$, LSD). Similarly, at this time streptomycetes from buckwheat-treated plots had greater average inhibition zones against $S$. scabies $(3.86 \mathrm{~mm})$ than streptomycetes from canola- and fallow-treated plots $(2.73$ and $2.82 \mathrm{~mm}$, respectively) ( $P<0.05$, LSD). In April 2002, nearly 11 months after GM incorporation, GM treatment had a substantial effect on the proportion of streptomycetes antagonistic against $S$. scabies $\left(F_{2,17}=2.74, P=0.093\right)$ (Table 1$), V$. dahliae $\left(F_{2,17}=6.75, P=0.007\right), F$. oxysporum $\left(F_{2,16}=1.87, P=0.187\right)$, and $R$. solani $\left(F_{2,16}=4.90, P=0.022\right)$, and on the average inhibition zone size against $V$. dahliae $\left(F_{2,17}=4.76, P=0.023\right)$ and $R$. solani $\left(F_{2,16}=3.34, P=0.062\right)$. When $V$. dahliae or $R$. solani were the target pathogens, soil from buckwheat- and canolatreated plots had greater proportions of antagonists than soil from fallow-treated plots (Fig. 4). Similarly, streptomycetes from buckwheat- and canola-treated plots had significantly larger inhibition zones against $V$. dahliae (3.43 and $3.16 \mathrm{~mm}$, respectively) or $R$. solani ( 3.63 and $3.92 \mathrm{~mm}$, respectively) than streptomycetes from fallow-treated soil (1.93 mm for $V$. dahliae and $2.21 \mathrm{~mm}$ for $R$. solani) $(P<0.05$, LSD). When $S$. scabies or $F$. oxysporum were the target pathogens, soil from canola-treated plots had greater proportions of antagonists than soil from fallow-treated plots $(P<0.05, \mathrm{LSD})$; buckwheat-treated plots were intermediate (Table 1; Fig. 4).

Relationships between inhibitory activity of streptomycetes, streptomycete density, and plant health: pathogen inhibition and potato health. Scab disease was correlated with streptomycete density, though correlations were not consistent between years. Among all plots in the first year of the trial, antagonist densities were usually negatively correlated with both percent scab $(R=-0.48$ to $0.32, P=0.016$, binomial) (Fig. 5) and mean number of scab lesions per tuber $(R=-0.74$ to $-0.41, P<0.001$ for type 2 or 3 lesions, $R=-0.80$ to $0.01, P=0.003$ for type 4 or 5 lesions, binomial). This is consistent with the hypothesis that a greater density of antagonistic streptomycetes would inhibit scab disease. However, in 2002, correlations between percent scab at harvest and the densities of antagonists of the four target pathogens estimated at the two sampling times were positive $(R=0.00$ to $0.49, P=0.004$, binomial). Correlations between scab intensity (percent scab or number of lesions) and the proportion of antagonists or mean inhibition zone sizes were inconsistent in 2001 and 2002.

Verticillium wilt ratings were consistently negatively correlated with both the mean inhibition zone size $(R=-0.44$ to -0.02$)$ and the proportion of antagonists $(R=-0.06$ to -0.39$)$ of each of the four target pathogens when all plots were considered at each sampling time in 2002 (eight of the eight correlations were negative for each measure of pathogen inhibition, $P=0.004$, binomial). Thus, in general, potatoes grown in soils with greater proportions of antagonistic streptomycetes and whose streptomycetes produce larger inhibition zones had lower Verticillium wilt ratings than potatoes grown in other soils.

Correlations between Verticillium wilt ratings and the proportion of antagonists varied among treatments. Among GM-treated plots, which had generally greater proportions of antagonists, Verticillium wilt ratings were negatively correlated with the proportion of antagonists of the four target pathogens (seven of the eight time-pathogen correlations were negative, $R=-0.30$ to 0.07 , $P=0.031$, binomial), while among all fallow-treated plots, correlations tended to be positive (five of the eight time-pathogen correlations were positive, $R=-0.41$ to $0.46, P=0.219$, binomial). This suggests that among GM-treated plots, but not fallow plots, disease suppression may be a function of antagonist inhibition of pathogens.

Correlations between Verticillium wilt ratings and the proportion of antagonists also varied among crop sequences. Among plots planted to corn the first year of the trial, there was a positive correlation between Verticillium wilt ratings and the proportion of streptomycetes antagonistic against $V$. dahliae $(R=0.59, P=$ $0.073), F$. oxysporum $(R=0.67, P=0.034)$, and $R$. solani $(R=$ $0.66, P=0.036)$ estimated in July 2002. Similar correlations among plots planted to potato or alfalfa were generally negative, though not significant. This suggests that factors other than pathogen inhibitory activity of streptomycetes as measured in this trial contribute to Verticillium wilt reduction in potato following the cultivation of corn.

Average tuber weight was consistently positively correlated with in vitro measures of pathogen inhibitory activity (antagonist density, proportion of antagonists, and average inhibition zone size) both years of the trial (data not shown). That is, tubers grown in soils having greater antagonist densities, higher proportions of antagonists, and larger mean inhibition zone sizes, in general, had greater mean weights.

Pathogen inhibition and the soil microbial community. Overall, streptomycetes from soils with greater densities and higher proportions of antagonists had larger inhibition zone sizes. Antagonist density was positively correlated with the average pathogen inhibition zone size at each of the five sampling times among all plots ( $R=0.23$ to $0.93, P<0.001$ to 0.181 ). In addition, at each of the five sampling dates, correlations between the proportion of antagonists against each of the four target pathogens

TABLE 2. Pearson correlation coefficients and associated $P$ values (in parentheses) for correlations between mean inhibition zone size and the proportion of streptomycetes antagonistic against each of the target pathogens among all experimental plots ${ }^{\mathrm{Z}}$

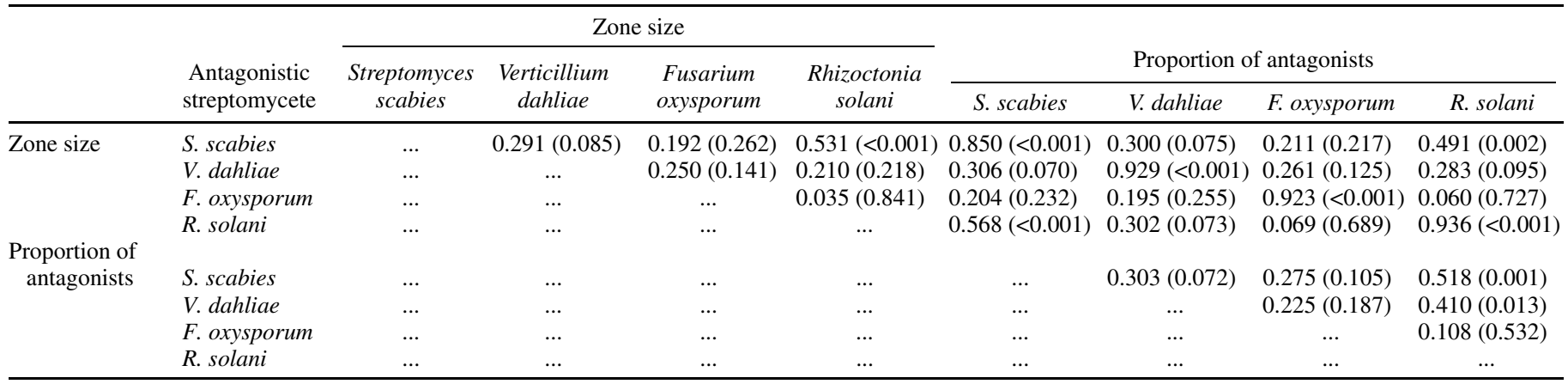

z Soil was sampled 30 April 2002. 
and the mean inhibition zone size of that particular pathogen among all plots were positive and significant $(R=0.85$ to 0.98 , $P<0.001$ ) (Table 2).

In general, soils with relatively high initial microbial densities were likely to have greater increases in pathogen inhibitory activity following GM treatment than soils with lower initial microbial densities. Among GM-treated plots, initial microbial densities estimated in April 2001 were positively correlated with the change in S. scabies $(R=0.35, P=0.098)$ and $V$. dahliae $(R=$ $0.36, P=0.091)$ antagonist densities from April 2001 to July 2002 , as well as the change in the proportion of streptomycetes antagonistic against $S$. scabies $(R=0.49, P=0.021)$ and $V$. dahliae $(R=0.53, P=0.011)$ and the change in mean inhibition zone size against $S$. scabies $(R=0.55, P=0.008)$ and $V$. dahliae $(R=0.42, P=0.054)$. In contrast, among fallowtreated plots, initial microbial densities were negatively correlated with the change in mean inhibition zone size against $R$. solani ( $R=-0.58, P=0.062$ ) from April 2001 to July 2002. This suggests that initial microbial densities influence the development of streptomycete pathogen inhibitory activity.

\section{DISCUSSION}

Despite the extraordinary complexity of microbial communities in agricultural soils, these results suggest that crop rotation and GM alone and in combination show promise as means to manage the streptomycete community to reduce plant disease. In particular, buckwheat GM reduced Verticillium wilt ratings and increased mean tuber weight compared with that of fallow controls. Though Davis et al. (9) also found that GM (corn or sudangrass) significantly reduced Verticillium wilt and increased mean potato tuber weight after two consecutive full seasons of GM crops, results of the present work indicate that significant wilt reduction can occur without loss of a production crop. The consistent negative correlations between Verticillium wilt ratings and measures of streptomycete pathogen inhibition (proportions of antagonists and mean inhibition zones) suggest that in vitro streptomycete inhibitory activity may be an important factor in predicting disease intensity. However, relationships varied among treatments. Among GM-treated plots, which had greater intensities of pathogen inhibition by streptomycetes, correlations were generally negative. In contrast, among fallow-treated plots, which generally had lower intensities of pathogen inhibition by streptomycetes, correlations between Verticillium wilt ratings and the proportion of

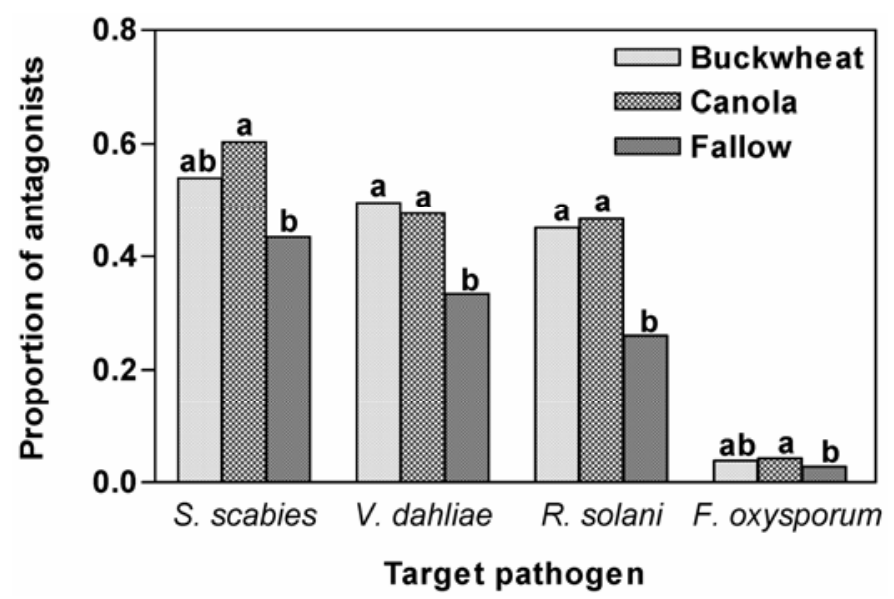

Fig. 4. Effect of green manure on the proportion of streptomycetes antagonistic against Streptomyces scabies, Verticillium dahliae, Rhizoctonia solani, or Fusarium oxysporum estimated in April 2002. Data shown are means of 11 (buckwheat) or 12 (canola and fallow) replicates per treatment. For each pathogen, bars with different letters are significantly different $(P<0.05$, least significant difference). antagonists were generally positive. This suggests that a critical value for intensities of pathogen inhibitory activity by streptomycetes may need to be reached before plant disease is suppressed. Moreover, the results indicate that incorporation of GMs may help shift the pathogen inhibitory activity of the soil to achieve Verticillium wilt disease suppression.

Potato scab disease was high both years of the study and was not significantly affected by GM treatments. These results are consistent with that of Weinhold et al. (46) in which they demonstrated that soybean GM did not suppress scab disease in a potato monoculture when the pathogen was already well-established, though soybean GM prevented scab disease increases in a potato monoculture when applied to naturally infested soils low in disease pressure. Thus, GMs may be most effective in suppressing scab disease when initial disease pressure is low or following multiple GM cycles. Despite the lack of significant disease control, the negative correlation between the number of scab lesions per tuber and in vitro pathogen inhibition by streptomycetes suggests that scab is influenced by inhibitory streptomycetes. In soils with greater pathogen inhibitory activities, the density of pathogens may be reduced or the ability of the pathogens to cause disease may be impaired. However, the lack of differences among GM treatments in their streptomycete pathogen inhibitory activity until almost a year after the first GM treatment was applied suggests that multiple cycles of GMs may be required for scab disease suppression when disease pressure is high.

Because it was unknown which target pathogens would provide the best index of pathogen inhibition and plant disease over time, four different target pathogens were assayed in the modified Herr method (17). At individual sample times, streptomycete inhibition of the four pathogens was consistently positively correlated among treatments. This suggests that the pathogen-suppressive soils have broad potential for inhibiting a diverse range of soilborne plant pathogens. Practically, the consistency in inhibition of different plant pathogens by a particular streptomycete community in soil suggests that studies of pathogen suppression may use a reduced number of target pathogens to be assayed, though it is possible that assays involving pathogens other than those tested in this experiment may vary. Of the four pathogens used, S. scabies and V. dahliae were the easiest to work with, producing plates least likely to be contaminated by other soil microbes and clear inhibition zones, and are recommended for further work. In addition, there was no optimum sampling time at which in vitro streptomycete pathogen inhibi-

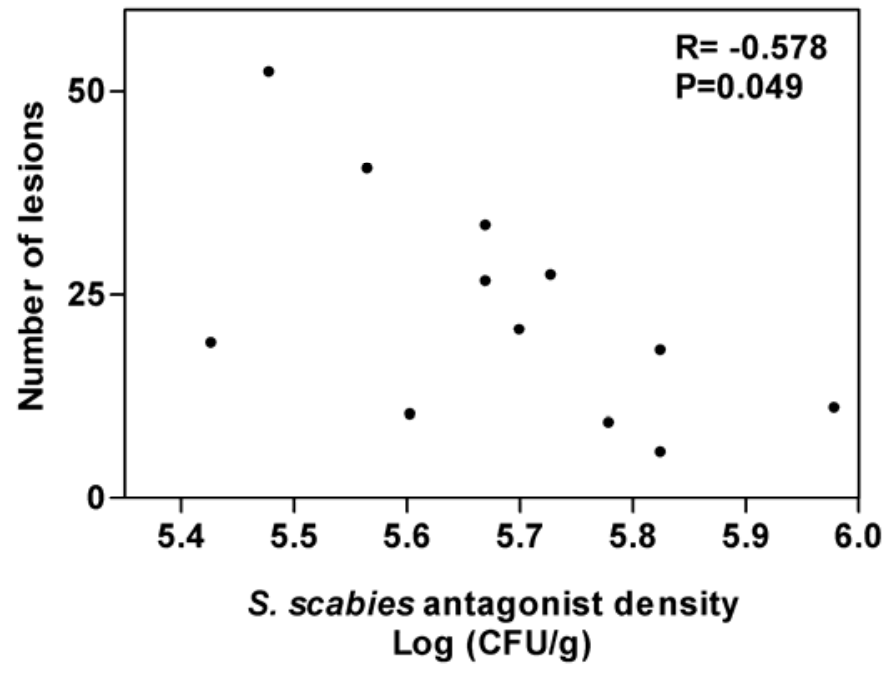

Fig. 5. Relationships between density of streptomycetes antagonistic against Streptomyces scabies estimated from soil sampled on 18 April 2001 and average number of lesions (type 2 or 3 ) per tuber among all plots. Values represent the Pearson correlation coefficient and associated $P$ value. 
tory activity was most strongly correlated with disease among all treatments.

Prior work has shown that brassica GM treatments, when incorporated into the soil, break down and produce antimicrobial compounds that directly reduce pathogen populations or growth, and thus plant disease $(7,32)$. In this work, however, canola GM treatment did not significantly reduce Verticillium wilt disease compared with that of fallow treatments. Non-brassica GMs have also been shown to reduce pathogen populations in soil. Previous research has demonstrated that Verticillium wilt of potato and Verticillium populations in soil decline after GM treatment of corn (9). In this trial, incorporation of corn residue into the soil after the 2001 growing season may have effectively served as a GM treatment in those plots resulting in the significantly lower Verticillium wilt disease intensity compared with plots previously planted to potato. Previous work by other researchers suggests that inhibition of Verticillium germination (8) and competitive inhibition by nonpathogenic Fusarium spp. $(9,21)$ may also contribute to reductions in Verticillium wilt of potatoes following organic soil amendments.

Although the results presented here concerning the effects of crop rotation are limited (a single rotation), these results support the well-known principle that crop rotation can provide an effective means for minimizing plant disease. Furthermore, cropping sequences involving potato have a profound effect on the soil microbial community. Previous work has demonstrated that potato monoculture can result in increased disease severity in the short term followed by reductions in disease severity in the long term and may ultimately result in suppressive soil $(23,29,34,46)$. A potato scab-suppressive soil that developed in Minnesota following long-term potato monoculture (29) had greater densities of streptomycetes, greater proportions of antagonistic streptomycetes, and streptomycetes isolated from these soils had greater mean inhibition zone sizes compared with that of nearby conducive soil (L. L. Kinkel, unpublished data). In this trial, soil from plots planted to potato in the first year of the trial had consistently greater densities of streptomycetes as well as antagonistic streptomycetes, and potatoes grown in these plots had more disease compared with other crop treatments. Although soil from these plots had greater pathogen inhibitory activities (greater antagonist densities) than other plots, corresponding increases in pathogenic streptomycetes may prevent a resulting reduction in plant disease. Rather, multiple potato crops may be required to allow the increases in antagonistic activity to cause a resulting decrease in disease. However, sustained potato monoculture is not a feasible management practice for growers.

Previous results have suggested that shifts in the inhibitory activity within the soil streptomycete communities following GM incorporation reflect a two-step process (L. L. Kinkel, unpublished data). First, GMs may select for enhanced population densities, with subsequent selection for increases in the frequency (density of antagonists) and intensity (mean inhibition zone size) of antibiotic inhibitory activities of the streptomycete community. Increases in the frequency and intensity of antibiotic inhibitory activities within high-density communities are hypothesized to reflect density-dependent selection for enhanced competitive abilities. In this work, neither GM nor production crop had any consistent effect on streptomycete or bacterial densities in soil. However, streptomycete communities in GM-treated soils had consistently greater proportions of pathogen inhibitors than communities in fallow-treated plots in the second season of the study. Thus, GMs may selectively enrich the abundance or activity of antibiotic producers within the soil microbial community. However, the lack of positive relationships between streptomycete density and the proportion of antibiotic producers among plots, as predicted by the model of density-dependent selection, suggests either that competitive pressure is not effectively indexed by density in this system or that selection for increases in the fre- quency of antibiotic producers by GMs may be mediated by processes other than competition.

Crop rotation and the use of GMs are practical management options for potato growers in Minnesota. Many growers already plant fall GMs and cover crops for the benefits conferred to the physical soil structure including increased organic matter and nutrients, improved soil structure, and reduced erosion $(1,2,4)$. These results indicate that buckwheat GM treatments can effectively reduce Verticillium wilt of potato in a naturally infested field and can increase mean tuber weight without taking the field out of production. Scab reduction may also be possible, though multiple cycles of GMs may be required. More broadly, these results suggest that active management of the soil microbial community, specifically pathogen inhibitory activity of streptomycetes, may be possible through the integrated use of GMs, and may contribute to suppression of a diverse collection of pathogens and diseases.

\section{ACKNOWLEDGMENTS}

This research was funded by a grant from the USDA NCR-IPM program (USDA CREES 2001-34103-10261). Canola 'Hyola 401' seed was generously donated by Interstate Seed Company, West Fargo, ND. We thank J. Katan, A. Davelos, and K. Xiao for careful review of the manuscript; and J. Flor, J. Gilpin, D. Johnson, and K. Hughes for their help in establishing and maintaining the field plots and their laboratory support.

\section{LITERATURE CITED}

1. Abdallahi, M. M., and N'Dayegamiye, A. 2000. Effects of green manures on soil physical and biological properties and on wheat yields and $\mathrm{N}$ uptake. Can. J. Soil Sci. 80:81-89.

2. Al-Khatib, K., Libbey, C., and Boydston, R. 1997. Weed suppression with Brassica green manure crops in green pea. Weed Sci. 45:439-445.

3. Becker, D. M., and Kinkel, L. L. 1999. Strategies for quantitative isolation of Streptomyces from soil for studies of pathogen ecology and disease biocontrol. Rec. Res. Devel. Microbiol. 3:349-362.

4. Blackshaw, R. E., Moyer, J. R., Doram, R. C., and Boswell, A. L. 2001. Yellow sweetclover, green manure, and its residues effectively suppress weeds during fallow. Weed Sci. 49:406-413.

5. Bulluck, L. R., and Ristaino, J. B. 2002. Effect of synthetic and organic soil fertility amendments on southern blight, soil microbial communities, and yield of processing tomatoes. Phytopathology 92:181-189.

6. Chamberlain, K., and Crawford, D. L. 1999. In vitro and vivo antagonism of pathogenic turfgrass fungi by Streptomyces hygroscopius strains YCED9 and WYE53. J. Ind. Microbiol. Biotechnol. 23:641-646.

7. Charron, C. S., and Sams, C. E. 1999. Inhibition of Pythium ultimum and Rhizoctonia solani by shredded leaves of brassica species. J. Am. Soc. Hortic. Sci. 124:462-467.

8. Conn, K. L., and Lazarovits, G. 1999. Impact of animal manures on Verticillium wilt, potato scab, and soil microbial populations. Can. J. Plant Pathol. 21:81-92.

9. Davis, J. R., Huisman, O. C., Westerman, D. T., Hafez, S. L., Everson, D. O., Sorensen, L. H., and Schneider, A. T. 1996. Effects of green manures on Verticillium wilt of potato. Phytopathology 86:444-453.

10. Davis, J. R., Huisman, O. C., Westerman, D. T., Sorensen, L. H., Schneider, A. T., and Stark, J. C. 1994. The influence of cover crops on the suppression of Verticillium wilt of potato. Pages 332-341 in: Advances in Potato Pest Biology and Management. G. W. Zehnder, M. L. Powelson, R. K. Jannson, and K. V. Ramay, eds. The American Phytopathological Society, St. Paul, MN.

11. Deacon, J. W., and Mitchell, R. T. 1985. Toxicity of oat roots, oat root extracts, and saponins to zoospores of Pythium spp. and other fungi. Trans. Br. Mycol. Soc. 84:479-487.

12. DeGroot, M. H. 1975. Pages 24-25 in: Probability and Statistics. AddisonWesley Publishing Company, Reading, MA.

13. El-Abyad, M. S., El-Sayed, M. A., El-Shanshoury, A. R., and El-Sabbagh, S. M. 1993. Towards the biological control of fungal and bacterial diseases of tomato using antagonistic Streptomyces spp. Plant Soil 149:185195.

14. Engelkes, C. A., and Windels, C. E. 1994. B-escin (saponin), oat seedlings, and oat residue in soil affects growth of Aphanomyces cochlioides hyphae, zoospores, and oogonia. (Abstr.) Phytopathology 84:1158.

15. Gottlieb, D. 1973. General consideration and implications of the Actino- 
mycetales. Pages 1-10 in: Actinomycetales: Characteristics and Practical Importance. G. Sykes and F. A. Skinner, eds. Academic Press, London.

16. Henis, Y., Sneh, B., and Katan, J. 1967. Effect of organic amendments on Rhizoctonia and accompanying microflora in soil. Can. J. Microbiol. 13:643-650.

17. Herr, L. J. 1959. A method of assaying soils for numbers of actinomycetes antagonistic to fungal pathogens. Phytopathology 49:270-273.

18. Hooker, W. J. 1981. Common scab. Pages 33-34 in: Compendium of Potato Disease. W. J. Hooker, ed. The American Phytopathological Society, St. Paul, MN.

19. Hornby, D. 1983. Suppressive soils. Annu. Rev. Phytopathol. 21:65-85.

20. Hoyos, G. P., Zambino, P. J., and Anderson, N. A. 1991. An assay to quantify vascular colonization of potato by Verticillium dahliae. Am. Potato J. 68:727-742.

21. Huisman, O. C., Davis, J. R., Sorensen, L. H., and Schneider, A. T. 1995. Soil suppressiveness of Verticillium dahliae infection on potato with cropping practices. Phytoparasitica 23:71.

22. Jones, C. R., and Samac, D. A. 1996. Biological control of fungi causing alfalfa seedling damping-off with a disease-suppressive strain of Streptomyces. Biol. Control 7:196-204.

23. Keinath, A. P., and Fravel, D. R. 1992. Induction of soil suppressiveness to Verticillium wilt of potato by successive croppings. Am. Potato J. 69:503-513.

24. Kinkel, L. L., Stromberg, K. D., Flor, J. M., and Wiggins, E. 2001. Green manures influence pathogen inhibitory potential of indigenous antagonist communities in soil. (Abstr.) Phytopathology 91(suppl.):S49.

25. Lambert, D. H., and Loria, R. 1989. Streptomyces scabies sp. nov., nom. rev. Int. J. Syst. Bacteriol. 39:387-392.

26. Lazarovits, G., Conn, K. L., and Potter, J. 1999. Reduction of potato scab, Verticillium wilt, and nematodes by soymeal and meat and bone meal in two Ontario potato fields. Can. J. Plant Pathol. 21:345-353.

27. Liu, D. 1992. Biological control of Streptomyces scabies and other plant pathogens. Ph.D. thesis. University of Minnesota, St. Paul.

28. Liu, D., Anderson, N. A., and Kinkel, L. L. 1995. Biological control of potato scab in the field with antagonistic Streptomyces scabies. Phytopathology 85:827-831.

29. Lorang, J. M., Anderson, N. A., Lauer, F. L., and Wildung, D. K. 1989. Disease decline in a Minnesota potato scab plot. Am. Potato J. 66:531.

30. Lorang, J. M., Liu, D., Anderson, N. A., and Schottel, J. L. 1995. Identification of potato scab inducing and suppressive species of Streptomyces. Phytopathology 85:261-268.

31. Lupwayi, N. Z., Rice, W. A., and Clayton, G. W. 1998. Soil microbial diversity and community structure under wheat as influenced by tillage and crop rotation. Soil Biol. Biochem. 30:1733-1741.

32. Mayton, H. S., Olivier, C., Vaughn, S. F., and Loria, R. 1996. Correlation of fungicidal activity of Brassica species with allyl isothiocyanate production in macerated leaf tissue. Phytopathology 86:267-271.

33. Mazzola, M., Granatstein, D. M., Elfving, D. C., and Mullinix, K. 2001. Suppression of specific apple root pathogens by Brassica napus seed meal amendment regardless of glucosinolate content. Phytopathology 91:673679.

34. Menzies, J. D. 1959. Occurrence and transfer of a biological factor in soil that suppresses potato scab. Phytopathology 49:648-652.

35. Millard, W. A. 1923. Common scab of potatoes. Ann. Appl. Biol. 10:70-88.

36. Millard, W. A., and Taylor, C. B. 1927. Antagonism of micro-organisms as the controlling factor in the inhibition of scab by green-manuring. Ann. Appl. Biol. 14:202-216.

37. Rouatt, J. W., and Atkinson, R. G. 1950. The effect of the incorporation of certain cover crops on the microbiological balance of potato scab infested soil. Can. J. Bot. 28:140-152.

38. Ryan, A. D., Kinkel, L. L., and Schottel, J. L. 2004. Effect of pathogen isolate, potato cultivar, and antagonist strain on potato scab severity and biological control. Biocontrol Sci. Technol. 14:301-311.

39. Samac, D. A., and Kinkel, L. L. 2001. Suppression of the root-lesion nematode (Pratylenchus penetrans) in alfalfa (Medicago sativa) by Streptomyces spp. Plant Soil 235:35-44.

40. Sanford, G. B. 1926. Some factors affecting the pathogenicity of Actinomyces scabies. Phytopathology 16:525-547.

41. Sanford, G. B. 1946. Soil-borne diseases in relation to the microflora associated with various crops and soil amendments. Soil Sci. 61:9-21.

42. Scholte, K., and Lootsma, M. 1998. Effect of farmyard manure and green manure crops on populations of mycophagous soil fauna and Rhizoctonia stem canker of potato. Pedobiologia 42:223-231.

43. Singleton, L. L., Mihail, J. D., and Rush, C. M. 1992. Methods for Research on Soilborne Phytopathogenic Fungi. The American Phytopathological Society, St. Paul, MN.

44. Treadwell, F. J. 1991. Breeding for resistance to Verticillium wilt in potato. Ph.D. thesis. University of Minnesota, St. Paul.

45. Weinhold, A. R., and Bowman, T. 1968. Selective inhibition of the potato scab pathogen by antagonistic bacteria and substrate influence on antibiotic production. Plant Soil 28:12-24.

46. Weinhold, A. R., Oswald, J. W., Bowman, T., Bishop, J., and Wright, D. 1964. Influence of green manures and crop rotation on common scab of potato. Am. Potato J. 41:265-273.

47. Wilhelm, S. 1951. Effect of various soil amendments on the inoculum potential of the Verticillium wilt fungus. Phytopathology 41:684-690.

48. Xiao, K., Kinkel, L. L., and Samac, D. A. 2002. Biological control of Phytophthora root rots on alfalfa and soybean with Streptomyces. Biol. Control 23:285-295.

49. Yuan, W. M., and Crawford, D. L. 1995. Characterization of Streptomyces lydicus WYEC108 as a potential biocontrol agent against fungal root and seed rots. Appl. Environ. Microbiol. 61:3119-3128. 